\title{
Challenging the Hegemons: the unheard story of a Brave Woman, Putalimaya Devi Poddar
}

\author{
Kalyani Pakhrin, Rajiv Gandhi fellow, \\ Dept. of Political Science, NBU.
}

The Nationalist Movement of India remains, an inspiring, entrancing and a saga of great sacrifice of flamboyant personalities. It contains the story of spectacular acts of courage and of silent but of solid constructive activity. It was a story of a grim battle against imperial exploitation and also an evolution of a 'nation in the making'. In this period there are stories of women who participated in the nationalist movement equally with men inspite of the fact that the society they were situated in was an equally oppressive social order. Women specially of the elite had educated middle class segment of the society were involved initially but the situation soon changed with the involvement of women in increasing proportion when the Congress led the struggle for national independence especially in the wake of Gandhi's pre-eminence on the Indian political scene in the post 1919 era.

However, it is unfortunate but noteworthy despite of women's great participation and their sacrifice in the India's struggle for freedom, women's role in the national endeavor for independence remains a much neglected subject area of research and study. This 'historiographic invisibility' is particularly lamentable not only because the 'woman question' formed an emotive and vital theme in the nationalist/ imperialist debate regarding Indian's 'fitness' for self governance, but also due to the fundamental fact that women's participation in and contribution to the country's quest for liberation from British imperialism constitute one of its most striking and remarkable features. The Gorkha people who migrated from Nepal and resided in the Darjeeling subdivision were under the British regime and were known for their bravery and fierce loyalty. In fact the British government had a Gorkha regiment comprised of Nepali speaking people. At the same time there were Gorkha people residing in Darjeeling who threw themselves into the throes of the freedom struggle of India as Indians. However, very little of this part of the Gorkha history is known especially about the women of this region who participated in the nationalist movement of India. The present study attempts to record and analyze how Puttalimaya Devi Poddar, a Gorkha lady and a heroine of the nationalist movement of India challenged not only the imperial order but also the social order of the day.

\section{Land of the Narrative}

The narrative is situated in the hills of Darjeeling a place in India that was famous for its suitability as a health retreat. The insertion of Darjeeling into British India is generally define as a place of an old and deserted Gurkha military station -Dorje-ling, or Darjeeling. Col. G. W. A. Lloyd claimed to have been the only European to see Darjeeling and J. W. Grant was assumed to be the originator of the idea of Darjeeling's suitability as a Sanatarium and for its cool climate for the purpose of enabling the servants of the government suffering from sickness to avail themselves of its advantages. The Darjeeling Tarai is a plain portion extending from the foot of the mountainous tract to the northern border of the Purnea district.It lies between 2630 '48" north latitude and between 88 29'east longitude.Its length from North to South is 18 miles and breath from east to west is 10 miles. The total area is of 229.95 square miles or $147,170.19$ acres exclusive of forest lands forming no part of this settlement.The northern side is bounded by the hill portion of the district, southern by Purnea district,eastern by Jalpaiguri district and western by independent state of Nepal.

In 1835, when British authority was extended to Darjeeling, it was virtually uninhabited with the population strength stood roughly around a hundred or so though formerly it boasted the residence of one of the principal Kazis and had been occupied by a large village. The population was mostly of Lepcha origin. When Campbell visited Darjeeling in 1839, he found there dense forest with negligible habitation. By the turn of the century, the population tally stood well above the two lakhs figure. British administrative penetration, especially the beginning of the tea plantation and commercial activity might have been primarily responsible for this radical transformation of demography. The population composition of 1901 reflects a predominance of Khas or Nepali speaking migrants. The numerical strength of Khas of Khaskura speaking people i.e., the Nepali speaking people from strict official viewpoint, was around forty-five thousands, but taking all other dialects of other groups of migrants from Nepal like Gurung, Murmi, Magari and others into consideration, the total number was nearly one and a half lakh. The Bengali and Hindi speaking people constituted approximately fortyfive and twenty- two thousand respectively. This demographic character of the region with predominance of 
Nepali speaking people has remained unaltered except for minor percentage fluctuations till this day. The hill regions of the district, in fact, marks an absolute (almost 90\%) domain of Nepali speaking people. This particular aspect undoubtedly has influenced the shaping of events in the district subsequently.

The first Census of India was published in 1872. There was an increase in the total population of Darjeeling to 94,712. The migration from Nepal continued to increase and when the second census of India took place in 1881 ,the Nepalis formed the absolute majority not only in the three hill sub-divisions but also in the whole district of Darjeeling.

\begin{tabular}{lrr} 
Population of Darjeeling District in $\mathbf{1 9 0 1}$ and 1941. & \\
\hline & Year1901 & Year 1941 \\
Rai (Jindar) & 33133 & 56794 \\
Tamang (Murmi) & 24465 & 43114 \\
Limboo & 14305 & 17803 \\
Mangar & 11912 & 17262 \\
Chettri & 11597 & 25941 \\
Kami & 9826 & 16272 \\
Gurung & 8738 & 15455 \\
Brahman & 6470 & 8999 \\
Bhujel & 5816 & \\
Newar & 5770 & 12242 \\
Damai & 4643 & 8162 \\
Sunuwar & 4428 & 4822 \\
Sherpa & 3450 & 6929 \\
Ghati & 3448 & 496 \\
Sharki & 1823 & 2778 \\
Sanyashi & 1151 & 1335 \\
Yakha(Dewan) & 1143 & 842 \\
Jogis & $752($ in 1931$)$ & 454 \\
Nepali Christians (as recorded) & 2,393 &
\end{tabular}

According to the Census of 1931 and upto 1941 there are two groups in hill tribes which are distinct from the people of the plains. The primitive people found in the North of the Province include not only the Bhotias, Thakurs and Totos but also the tribe with an origin in Nepal. Of this tribes the Tiparas only are shown as a deepest clause with of an anomaly.

\section{CENSUS OF 1931:-}

Report of Census Operation,1931 and upto 1941

Hill Tribes. Census Report of Siliguri -1898 and Darjeeling-1901

Description of Tribes

Census Figure for the year

\begin{tabular}{|c|c|c|c|c|c|}
\hline & 1898 & 1901 & 1931 & 1941 & 1961 \\
\hline Bhutia of Sikkim(ST)* & 422 & - & 975 & - & $\mathrm{B}$ \\
\hline Bhotia of Bhutan(ST)* & - & - & 2,843 & - & $\mathrm{B}$ \\
\hline Bhotia of $\mathrm{Nepal}(\mathrm{ST})^{*}$ & - & - & 6,855 & - & B \\
\hline Bhutia of Tibet(ST)* & - & - & 4,103 & - & B \\
\hline $\operatorname{Brahman}(\mathrm{OBC})$ & 630 & 6,470 & 118 & 8,999 & $\mathrm{H}$ \\
\hline Khas(Chhettri-OBC) & - & 11,597 & 225 & 25,941 & $\mathrm{H}$ \\
\hline $\begin{array}{c}\text { Gharti(Bhujel/Khawas) } \\
\text { (OBC) }\end{array}$ & 129 & 3,448 & 2,187 & 496 & $\mathrm{H}$ \\
\hline Gurung(OBC) & 1,916 & 8,738 & 13.011 & 15,455 & B \\
\hline Jimdar(OBC) & & 33,133 & 11,144 & - & $\mathrm{H}$ \\
\hline Khambu(Rai) & 2,773 & - & 32,601 & 56,794 & $\mathrm{H}$ \\
\hline $\operatorname{Rai}(\mathrm{OBC})$ & - & - & 6,273 & - & $\mathrm{H}$ \\
\hline Yakha(Rai) & 57 & - & 873 & - & $\mathrm{H}$ \\
\hline Lepcha(ST)* & 1,124 & - & 11,719 & - & $\mathrm{H}$ \\
\hline Limboo/Subba(ST)* & 524 & 14,305 & 17,623 & - & $\mathrm{H}$ \\
\hline Magar(OBC) & 524 & 11,912 & 24,018 & 17,262 & $\mathrm{H}$ \\
\hline $\operatorname{Murmi}($ Tamang)(ST)* & 1,002 & 24,465 & 34,911 & 43,114 & B \\
\hline Newar(OBC) & 507 & 5,770 & 12,627 & 12,242 & $\mathrm{H} / \mathrm{E}$ \\
\hline Sherpa(ST)* & - & - & - & - & $\mathrm{H}$ \\
\hline
\end{tabular}




Thami(OBC)
Sunuwar/Mukhia/Koinch(OBC)
Thakuri/Shaha/Malla(OBC)
Sannesi(OBC)
Kumhal(OBC
Gaine(OBC)
Kami(SC)**
Damai(SC)**
Sarki(SC)**
Koche(ST)
Meche(ST)

$\begin{array}{lllll}- & - & - & - & \mathrm{H} \\ - & - & - & - & \mathrm{H} \\ - & - & - & - & \mathrm{H} \\ - & - & - & - & \mathrm{H} \\ - & - & - & - & \mathrm{H} \\ - & - & - & - & \mathrm{H} \\ - & - & - & - & \mathrm{H} \\ - & - & - & - & \mathrm{H} \\ - & - & - & - & \mathrm{H} \\ - & - & - & - & \mathrm{H} \\ - & - & - & - & \mathrm{H}\end{array}$

Though all the above were declared as Hill Tribes by the census upto 1931, after implementation of British India Act (1935) and appointing Bengal as an Acting Agent, procedure of treating as 'Hill Tribes' was unknowingly left over. After independence they were seek to bound their own identity.

These castes of Gorkhas are the subjects of those territories which were ceded from Nepal, Sikkim and Bhutan as well as recruitment in the Defense during British India and stands original citizens of India after independence.

Abreviation $=*=\mathrm{ST} . * *=\mathrm{SC}$, rest are $\mathrm{OBC}, \mathrm{B}=\mathrm{Buddhist}, \mathrm{H}=$ Hindu.There are (1) Christians also, (2) Many Bengali, Behari, Punjabi, Marwari, Muslims and other tribes including Santhal, Rajbanshi, Kochay and Mechay of Gorkha class.

Ethnical Census report is not available from 1951. However, it can be estimated that the population of nonGorkha communities started to increase from 1961 and onwards as Darjeeling District was absorbed in West Bengal only from $30^{\text {th }}$ April 1954.

\section{Nepali Society and the Status of Women}

By the mid $19^{\text {th }}$ century till date, the ethnic composition of the three hill sub-divisions of Darjeeling had undergone a sea-change which has also have had its impact on the caste structure. This was evidently caused by the waves of massive migration from Nepal due to three major factors. Firstly, in the second half of the $18^{\text {th }}$ century, the ascendancy Prithvinarayan Shah, the founder of Gorkha dynasty in Kathmandu unleashed an aggressive drive of the high caste Hindu monarchy of Nepal for centralization and expansion. This caused socio-economic tensions inside Nepal and imposed a repressive measures of dominations of high caste Hindu Nepalis over the the Buddhist and other non-Hindu Nepali tribes and communities. The Kirat reason was particularly a tribal land marked by the system of "Kipat" land holding which was a kind of community land ownership system. Hence, such "Kipat" lands wasted in a particular ethnic group could not be permanently alienated. But, after the establishment of Gorkha Supremacy over the "Kirat" region in eastern Nepal undergone a change of collective ownership of the "Kipat" lands in the Royal possessions making the Nepali tribes of the region landless. The Nepali communities such as the Rais, the Limbus, the Gurungs and the Tamangs in the "Kirat" region were downgraded to the status of "Sudra" making them vulnerable to the oppression of the Brahmins and the Kshatriya caste. These Nepali tribes did not have any conformity to Hindu scriptures invited serious punishment known as "panchakhat" which included confiscation of property, banishment, mutilation, enslavement and even death. Thus, a large number of Rais, Limbu, Gurung, Tamang and other low caste Nepalis started migration from the eastern region of Nepal. They found the Brithsh India, particularly the hill sub-divisions of Darjeeling a convenient and accessible place for settlement.

Secondly, the willingness of the English tea planters to encourage settlement of the Nepali migrants as a plantation workers of the tea gardens of the hill sub-divisions of Darjeeling. The English assumed that the Nepali migrants were hard working and could adapt themselves to the working conditions of the tea gardens which were situated at the high altitude in the hills of Darjeeling,Kalimpong and Kurseong. The English planters for tea gardens in the Terai region preferred the tribal from the Chhotanagpur region of Bihar such as Santals and the Oraons. However, due to their poverty-stricken background both the Nepali migrants and the tribals from Bihar could be recruited with low remuneration throughout the second half of the $19^{\text {th }}$ century and the early decades of the present century. Thus, in the initial phase there was a rapid flourished of tea industry in Darjeeling.

Thirdly, the British policy of recruiting the Nepalis for the Gorkha Battalions in the Indian army encouraged migration from Nepal to Darjeeling. However, the basic reason for this was the British recognition of the Gorkha loyalty which was amply proved during the Sepoy Revolt of 1857. Beside this the British Rulers also encouraged the recruitment of Nepali migrants in the police service as well as in various construction works connected with the growth process of Darjeeling as a Sanatorium and a tourist centre. 
Therefore, the major factor which motivated the British rulers to encourage the Nepali migrants throughout the second half of the $19^{\text {th }}$ century was to out balance the original ethnic domination of the Lepchas and the Bhutias in the region. The British had the perception that the Lepchas and the Bhutias were unlikely to shift their loyalty from Tibets as they were strongly integrated by a common heritage, religion, language and culture.

On the other hand the Nepali had not only proved their loyalty to the British during the Sepoy Revolt of 1857 but also they were mostly Hindus. These Nepalis were considered to be the traditional enemy of the Buddhist Tibetans and the Buddhist Bhutias. The British felt that here the religion will play a leading role and the Hinduism will assuredly cast out Buddhism. Since there was a rapid emergence of the dominant position of Nepalis in the ethnic composition of Darjeeling, the second half of the $19^{\text {th }}$ century saw the composition of Darjeeling accompanied by the settlement of a small number of Bengali middle class families from plains. They not only hold administrative services and learned professions in the urban areas of the hill sub-divisions but also assumed managerial and clerical services in the tea gardens. The Biharis and Marwaris also started to settle in small numbers as a whole sale dealers and retail trade of the district. In 1941, the population figures of the Bengalis, the Biharis, the Marwaris and the others coming from the plains did not constitute more than 5.1 percent of the total population in three hill sub-divisions of the districts, whereas 86.8 percent of the population were Nepali speaking. Beside this, the other hillmen and the scheduled caste formed another 8.1 percent. Whereas in Siliguri the sub-division of Darjeeling district, included mostly the plains and a part of the Terai forests and a segment of tea gardens, the majority of population was constituted by the Bengalis which further increased after the influx of the refugees following the partition of Bengal in 1947.

Therefore the ethnic complexities mentioned above of the Darjeeling district, a composite culture started taking shape in the three hill sub-divisions from the beginning of the present century. The bond of unity was provided by the Nepali language which in Nepal used to be known as 'Khaskura' or 'Gorkha' by the end of $17^{\text {th }}$ century. However, in Nepal 'Khaskura' language remained mostly confined to the upper caste of BrahminChettris even after the Gorkha ascendancy under Prithvinarayan Shah and a link could not easily form for linguistic or cultural affinity with the various low caste ethnic groups of Nepal who spoke Tibeto-Burman languages. Whereas, in Darjeeling the situation was altogether different. This 'Khaskura' of the upper caste was picked up as a second language by the low caste Nepali immigrants like the Rais, the Limbus, the Pradhans, he Gurungs, the Tamangs and the Kirats, who spoke Tibeto-Burman dialects. Hence, in India, in general and in Darjeeling, in particular, gradually Nepali language forged a bond of cultural unity and ethnic link among various groups who had migrated from Nepal. The Lepchas and the Bhutias too, inspite of their religious and linguistic differences with the Nepalis, slowly but ultimately accepted Nepali as the lingua franca in the hill subdivisions of Darjeeling. Towards the end of $19^{\text {th }}$ century it became a hard reality due to overwhelming demographic predominance of the Nepalis which contributed to the acceptability of Nepali language as the lingua franca. Beside this, another major contributing factor was the steady permeation of the process of Sanskritisation of the low caste Nepali migrants. From the beginning of the present century there was a gradual increase in the number of upper caste Chettri and Brahmins migrants from Nepal which contributed to the growth of Hindu places of worship in Darjeeling and subsequently outnumbered the Buddhist monasteries. However, in course of time, there started and influence of Buddhism on the low caste Nepalis like the Tamangs, the Rais and the Limbus started decreasing and most of them gradually embraced Hinduism. The Lepchas even could not avoid the process of Sanskritisation. In Darjeeling, the ethnic unity was further reinforced by the settlement of large number of retired Nepali officers of the British Indian Army as well as Nepali Police Personnel, who were regarded as a "Loyal" immigrant by the British in the hill sub-divisions of the district.

A composite Nepali culture was striking its early roots in Darjeeling but the Nepali communities remain stratified along the economic lines. The land holding class, the retired army and police officials represented the aristocratic elements, while the other major strata were formed by the middle class service holders, small traders and by the working class consisting of plantation and construction workers as well as small peasants and agricultural labours. Thus, the ethnic identity of the Nepalis made a great effort to cut across these major economic strata and sought to express itself in two distinct streams which sometimes flowed together. The first one was to spread Nepali language and literature regarded as the focal point for the composite ethnic culture of the hill sub-divisions of the district. The second one was the ethnic identity of the Nepalis which was expressed in terms of an exclusiveness gradually took in shape through demands for various forms of autonomy for Darjeeling.

The Nepali society was steeped in social practices like child marriage, dowry, sati, Purdah etc. It was a hierarchised society with caste practices deeply ingrained within the social fabric. Particularly the society was too rigid and tradition bound. During the period, in the Nepali society there was an existence of hierarchical caste structure which is prevalent till date. The caste structure was generally divided into higher level and lower level. There were four divisions in the caste system namely- Brahmanas, Kshetriyas, Vaisyas and Sudras.The Brahmanas consisted of Upadhyay, Sharma, Dahal, Upreeti etc. The Kshetriyas consisted of Chettri, Newar etc. In Vaisyas there are Gurung, Mangar, Tamang, Subba, Rai etc. In Sudras there are Kami, Damai and Sunar. 
There was a separate community within the Nepali society which was known as Tribal. The tribal community consisted of Sherpa, Bhutia, Lepcha and Yolmo. The marriage in those days was considered to be the most important part of social life. The marriage generally existed only within the same caste and if there was any inter-caste marriage than the person was not only boycotted from the family but was socially boycotted. This was due to the fact that the caste hierarchy was too rigid during the period and any transformation in this was strictly prohibited by social system of Nepali Community.

The women hardly received any form of education as they were not allowed to have any educational facilities or other sort of facilities which would develop them. The only work that they were given was to reproduce a child and raise them and to look after the domestic household. There was no system of inter-caste marriage too and if any one dared to do that then she had to face social boycott within the family and society.

Beside this the women's lives were segregated even within their homes and they did not have any social contacts with any of the men in the family except her husband and they had to keep their head covered and it was rigorously practiced. They were secluded and confined to the room even after marriage. Thus the women found themselves oppressed by the traditional hierarchical structure causing gender inequalities. They were not allowed to question the order of the father and right from their birth they were dominated by the males within their family.

\section{The Heroine of the Narrative: Puttalimaya Devi Poddar}

Putalimaya Devi Poddar was born on $14^{\text {th }}$ January 1920 in Burdwan road in Kurseong. She was the eldest daughter among the four siblings of Manbahadur Tamang. In 1934-35, one unknown man was seen wearing Khaddar cloth in Kurseong. This inspired Harish Chettri and Putalimaya Devi in joining the freedom movement. The person was none other than Saryu Prasad Poddar who was a congressman and had come from Bihar. Hence, Harish Chettri came across Poddar and joined the congress party. During the period Putalimaya Devi was 14-15 years of age. She too wanted to join the movement for freedom but the society in those days were very conservative towards women's involvement in the movement and besides this the British Government declared that any person who is a close associate of the congress would be considered illegal. But this could not stop Putalimaya as she had very strong patriotic feelings and with the help of Harish Chettri she finally met Saryu Prasad Poddar to whom she expressed her desire to participate in the movement. Since then, no congress work or congress office was opened in Kurseong. Saryu Prasad, considering Putalimaya's age asked her to return back to school. While studying in school, Putalimaya always met the congressmen and kept all the information about the congress activities in the country. By the end of 1936, with the help of Pratiman Singh Lama, Harish Chettri and Savitri Devi the Congress Saka Karyalai (Branch Office) was finally opened in Kurseong. During this period she was in class 9 and when the Congress Committee was established Putalimaya became the member of the congress party. Hence, she played a vital role in the freedom movement. But this was protested by her father Madan Bahadur Tamang who did not want her to get involved. Madan Bahadyr Tamang was a "chaukidar" (watchman) in the Municipality and was threatened regularly by the British to stop his daughter from being involved in the movement. Even an officer (Maukama Adhikari) called her in his office and offered her a job as a nurse in the Kurseong hospital but nothing could stop her from participating in the movement. This all made her more dedicated towards the movement and she became more active in her work. Her struggle was not merely to oust imperial subjugation but also against the established social order that she realized was an artificial creation to subjugate a large segment of the society.In 1913, Putalimaya started a Harijan Samaj (Committee) in Kurseong. She inspired the Harijan people for education and started a school in Harijan building to educate them. She also realized that women too needed a platform through which they could participate equally with the men in the freedom movement of India. She was farsighted enough not to just restrict the fervor of patriotism among the adult men and women but made women the messengers of the message of patriotism to be taken back home and to inspire the minds of the children so that the entire community gets motivated and inspired by the feeling of nationalism. With this objective in mind, in the same year she also formed the women organization that manufactured Khadi cloths and were taught to spread patriotic feelings among the children. All these activities made her notorious to the British Government and she was called at the police station where she received a warning that she should leave the movement. Slowly the common people started getting associated with the movement. Both the Harijan Samaj and the women's organization became very strong among the common people. In Mahila samiti the women openly started preaching the nationalist movement by keeping the photograph of Gandhiji. In all the hill sub-divisionsKurseong, Darjeeling and Kalimpong the Congress samiti began to hold a strong position.

On $8^{\text {th }}$ August 1942, in Bombay, there was a huge slogan of swaraj and on $9^{\text {th }}$ August all the prominent leaders were arrested. On $12^{\text {th }}$ August in Kurseong a huge Jan Sabha was organized and on that day Saryu Prasad was arrested. On $13^{\text {th }}$ August Putalimaya who was then 22 years of age organized a huge procession in Kurseong along with Harish Chettri, Janaklal Kulmi etc. where all of them were arrested. This incident led to huge protest by the people who surrounded the police station with the demand of the release of 
their leaders or to arrest them too. The policemen were very much frightened by this act and from backdoor took all the arrested leaders to the Palikan Tourist Lodge through the garden and were sent to Darjeeling jail with the help of a vehicle. The British Government asked them to sign a letter which would prevent them from participating the movement but the leaders refused to do so and all the leaders were kept in jail with the criminals. Even in jail the leaders demanded for all the provisions that a Rajnaitik Kaidi (political prisoners) receives and went for a hunger strike. Finally their demand was accepted. During her stay in jail Putalimaya read Gita and did spinning every day.

In 1941, Women's Association (Mahila Mandali) was established in Kurseong. Maya Devi Chettri, a prominent Nepali Freedom Fighter for the first time participated in the outdoor activity as a vice- president of the association. Again in the same year, Dil Bahadur Chettri who was also a Freedom Fighter opened "Hindukanya Pathshala"(Girl School) in "Pratham Grokhajan Pustakalaya"(First Gorkha Library) in Kurseong. Maya Devi Chettri worked as a Principal but due to economic constraint the school had to be handed over to Kurseong Municipality.

The most remarkable event which occurred in the period, was the establishment of Shri Ramkrishna Girls High School in Kurseong. Although Scottish missionaries undertook the construction of schools and welfare centres like Loreto Convent in 1847, St. Paul's School in 1864, but these were mainly for the British residents and the elites of Bengal and not for the common masses of the region. Therefore, the establishment of Ramkrishna Girls High School in Kurseong could be considered as the first major move towards the social reform movement in the region regarding the female education. Earlier the girl's education was limited up to the primary level. But, with the establishment of this school, it provided a breakthrough not only in the system of education for girls but a challenge towards the orthodox system of society where girl's education were treated with suspicion and non acceptable. The nine girls students of Shri Ramkrishna Girls High School, Kurseong were qualified to be President's guide with Maya Devi Chettri as an Assistant Commissioner for Giri Guides and others. They all participated in All India Rally of President's Scouts and Guides. These were remarkable events in the sense that it signaled the arrival of the times of change.

Establishment of schools and initiatives taken to open the doors of enlightenment to women was also signaling the dawning of a new era of light but there were some more shackles that had to be broken.

On January 1944, she was released from jail but her health deteoriated due to her long stay in jail. This act of her made her parents very upset. On the same year Saryu Prasad Poddar too was released. Since Putalimaya's domestic life was very disturbed, her parents threatened her either to leave the movement or family. But Putalimaya Devi chose to continue her active role in the movement instead of her family.

In such a situation all the Congressmen suggested both Saryu Prasad Poddar and Putalimaya to get married which was not an easy task. The marriage was an inter-caste and the people of Darjeeling were not willing to consider this marriage which was against the customs and traditions of the Nepali community. A huge number of people surrounded the 'Gorkha Janak Pustalaya(library) by holding Khukuri (a traditional dagger like weapon) in their hand with the intention to stop the marriage ceremony. Putalimaya devi's parents were also against this marriage because Surendranath Poddar was a behari man and Putalimaya Devi was Nepali woman. The most significant role played against the marriage was by two person named Hanseh and Bhombey who were the local dada in the region, said "Herui Tyo Madisele Kasari Hamro Nepali Chelilai Biye Gardo Rahecha"(let see how this behari marry our nepali daughter). There was a huge protest from all over the community. Amongst the Nepali community Mrs. T.B.Pradhan played a very important role in favour of the marriage and stood outside the Pustalaya holding a naked Khukuri in her hand by chasing away all the protesters. She said "Harau Katiko Babuko Chora Rahecha, Mopani Gorkha Hui"(let see who has so much of courage to stop the marriage, I am also a Gorkha). When the day of marriage was held the local people not only protested the inter-caste marriage but also threatened those who would participate in the marriage ceremony. Ultimately there was for the first time an 'inter caste marriage' in 'Gorkha Janak Pustalaya'. Thus, Mrs. T.B.Pradhan and her daughter Hira Pradhan and niece Chandra Pradhan played a significant role not only in getting the inter-caste marriage successful but also helping them physically and financially after the marriage. After marriage both of them faced economic problems due to the lack of income source. There were days when they stayed without food but continued their activities for the freedom movement.

After independence she continued her work as Samaj Sevika and the member of the congress party. The common people called her 'Mataji' and was respected by all the people including the downtrodden for whom she was a god sent person on earth. The Government of India awarded her by the name 'Swatantrata Senani' and 'Tamra Patra'. She was also provided with a senani pension for lifetime. Till her death she worked as a President of mahukuma Congress Committee of Kurseong and Vice-President of Darjeeling Zilla Committee. She died on $1^{\text {st }}$ December 1984 in Siliguri hospital due to her prolonged illness. 


\section{Conclusion}

The caste hierarchy that existed in Darjeeling during that period was the upper caste did not encourage within them mixing in the form of marital relations in the form of intercaste marriage, such as Brahmins and Chettris who tried to maintain its honour and this system is prevalent till date. They maintained tight marriage system which did not permit inter caste marriage because of the rigidities of endogamous marriages. Perhaps love between communities, or between caste doomed to failure since any exercise of choice or agency or rather any relationship based on genuine consent of the partners was interpreted as a defiance of caste hierarchy and a threat to endogamy. Thus it was passed off as tradition, or culture and most of all as honour of the families of the upper caste.

Thus, one should note that in such conservative society the participation of women in the movement led them to fight against dual system, one the cast hierarchy and social control and second the colonial regime. Their participation in the public domain as well as the new awareness helped them question the bondage of traditions and helped them to develop a perspective on wider socio- political problems. For example Puttalimayadevi Poddar, the way she challenged the caste structure of the society by marrying a Bihari man in a period which was marked by a highly conservative social order that was oppressive for women,and by joining the nationalist movement against her father's wish, challenging the patriarchal order, shows a clear picture of such brave woman who survived through all odds and was successful in coming to the limelight as a brave heroine of the century. In the process was a heightened political awareness and much greater social consciousness among women. The prevailing political environment and values, seem to have positively encouraged the activities of women to move beyond traditional roles. Thus, there was a shift in the roles of women from a supportive auxiliaries to direct participation and there was a conversion of leadership that women were coming as leaders. Hence, the ancient prejudices melted, walls of tradition cracked and the rays of new hope started creeping in. Therefore, the independence of women showed an upward trend.

\section{References}

[1]. ABP (July 24,1930),p.3, (July 26,1930),p.5. A case for Constitutional Recognition of Nepali. AINBS-Darjeeling, 1976.

[2]. A case for Constitutional Recognition of Nepali. AINBS-Darjeeling, 1976.

[3]. B.T. Ranadive: 1986, Gorkhaland Agitation: A Part of Imperialist Plot in East. September, 1986.

[4]. Bagchi, G.C,1972. Village Survey Monograph on Upper Pedong. Census of India, 1961.

[5]. Bista, D.B.1980. People of Nepal. Kathmandu: Ratna Pustak Bhandar.

[6]. Campbell, A. 1905. Final Report on the Survey and Settlement of the Kalimpong Government Estate in the District of Darjeeling, 1901-1903. Calcutta: Bengal Secretariat Press.

[7]. Chemjong, Iman Singh.1966. History and Culture of the Kirat People. $3^{\text {rd }}$ Ed.Nepal:Tumeng Hang.

[8]. Caplan,I,1970. Land and Social Change in east Nepal: a study of Hindu-tribal relations.

[9]. London; Routledge and Kegan Paul.

[10]. Chettri,V.1994, Kumar,Kurseong Ra Kishorawasthama, Kuseong, In Nepali.

[11]. Darjeeling Branch Indian Tea Association. 1982. Report. Submitted to the Deputy Commissioner of Darjeeling.

[12]. Dash, Arthur Jules.1947. Bengal District Gazetteers: Darjeeling. Calcutta: Govt. Printing.

[13]. De, P.J. 1978. "Study of a Market in Darjeeling District, West Bengal”. Bul. Of Anthrop.Sur. of India, 27 (1\&2).

[14]. Dozey, E.C. 1922. A Concise History of the Darjeeling District since 1835 with a complete Itinerary of Tours in Sikkim and the District. Calcutta: Art Press.

[15]. Dartmouth College (1989); ABP (April 20,1930), p.6, (November 7, 1930),p.4, (November 23, 1930), p.5; BC (July 14, 1930), p.4, (November 7, 1930), p. I (December 7, 1930), p. I,(January 3, 1931), p. I; The Tribune (August 7, 1930), p. 9.Darjeeling: 1850, from Illustrated London News, 1850.

[16]. Dasgupta. Atis, 1999, Ethnic Problems and Movement in Darjeeling, Social Scientist, Vol. 27.

[17]. Dasgupta Manas: 1989, Economic Development of Darjeeling Hill Areas.

[18]. Desai I.P: 1967, “Caste Politics” in Economic and Political Weekly(Bombay), April 22

[19]. Foning, A.R.1987.Lepcha: My Vanishing Tribe. New Delhi: Sterling.

[20]. Gorkha National Liberation Front. 1986 “Gorkhaland is a Must Why?”. Leaflet Gorkhaland Agitation: An Information Document, Govt. of West Bengal,September 1986.

[21]. Government of West Bengal, Office of the Deputy Commissioner of Darjeeling, Tribal Gorkhaland Agitation: An Information Document-II, Govt. of West Bengal, January, 1987.

[22]. Welfare Department, $22^{\text {nd }}$ May, 1958.

[23]. Hermanns, Fr. Mathias. 1954. The Indo-Tibetans: The Indo-Tibetans and Mongoloid Problem in the Southern Himalaya and NorthNortheast India. Bombay: K.L.Fernandes.

[24]. Himalayan Times. 1948. Jul 18.Kalimpong H.H. Risley: 1894, The Gazetteer of Sikkim.

[25]. Himalayan Times,2008, Kalimpong Vol. III, Issue 8, November.

[26]. History of Darjeeling. exploredarjeeling.com. Retrieved on 2 May 2006

[27]. Kothari Rajni: Politics in India(Boston: Little Brown and Co. 1970),p.237.

[28]. Lama, Ratna Mani, 1996. 'Prenahko Shrot Maya Devi', Darjeeling, Vistha Publication, Darjeeling. In Nepali.

[29]. L.S.S. O’Mally: 1907, The Gazetteer of Darjeeling.

[30]. Moktan.R, 2004, Sikkim:Darjeeling Compendium Of Documents,Sumaralaya Publication,

[31]. Kalimpong.

[32]. Munsi, Sunil.1980. “An Enquiry into the Nature of Frontier Settlements: Case Study of Hill Darjeeling”. Occasional Paper Number 34. Centre for the Studies in Social Sciences, Calcutta.

[33]. Nepali,GS,1965. An ethno-sociological study of a Himalayan Community. Bombay, United Asia.

[34]. Nagree Samiti, , 'Kalimpongka Swatantrata Sangramiharu', Publication: Kalimpong. In Nepali.

[35]. Nepali, Gopal Singh. 1965. The Newars: An Ethno-Sociological Study of a Himalayan Community. Bombay: United Asia. 
[36]. Nepali Sahitya Sammelan, Darjeeling Publication 'Swatantrata Senani Dalbahadur Giri'.

[37]. In Nepali Northey, WB and Morris, CJ.1974. The Gorkhas: their manners, customs and country.

[38]. Delhi, Cosmo Publications.

[39]. Pinn, Fred. 1986 The Road of Destiny: Darjeeling Letters 1839. Calcutta: Oxford University Press

Poddar.Prasad.Saryu,1987,Swadhinta Sangran,Darjeeling Aou ma,Shiv Publication, Kurseong.

[40]. Rai, M.P,1992, Bir Jati Ko Amar Kahani, Aajako Sikkim Prakashan, Arithang, Gangtok, In Nepali

[41]. Ratandhwaj Rai, 1937, Laden La.Darjeeling Popular Agency.

[42]. Rosser, C.1966. Social mobility in the Newar caste system-In Furer Haimendorf(ed): Caste and kin in Nepal, India and Ceylon, Bombay; Asia.

[43]. Samanta.K.Amiya, 1996, Gorkhaland-A study in ethnic separation. New Delhi. 